\title{
Occurrence and Transmission of Grapevine Virus A in South African grapevines
}

\author{
D.J. Engelbrecht and G.G.F. Kasdorf \\ Plant Protection Research Institute, Private Bag X5017, Stellenbosch 7600
}

Submitted for publication: December 1986

Accepted for publication: March 1987

Keywords: Grapevine virus A, Grapevine leafroll, ELISA, mealybug transmission, closteroviruses

\begin{abstract}
Antiserum prepared to a local isolate of grapevine virus A (GVA) was used in immunosorbent electron microscopy (ISEM) with decoration and in an unlabelled antibody enzyme-linked immunosorbent assay (ELISA) for the screening of grapevine sources for the presence of virus. GVA occurred extensively in grapevine plantings showing visual symptoms of leafroll or indexing positive for leafroll. GVA was found not to be associated with either stem pitting or fleck symptoms. It occurred mostly in association with undecorated closterovirus (CV)-like particles. Limited ISEM with decoration of the CV-like particles using antiserum to a Swiss isolate of CV $2200 \mathrm{~nm}$, (CV type I) confirmed the presence of a second $\mathrm{CV}$ in local grapevine sources. In addition, it indicated the presence of a third $\mathrm{CV}$-like particle longer than GVA. GVA together with undecorated CV-like particles were also detected in initially GVA-free LN-33 grapevines growing under field conditions and naturally infected with leafroll. GVA and CV type I were also present in the vine mealybug Planococcus ficus, following exposure to a grapevine source carrying these viruses. However, due to lack of $C V$ type I antiserum, only GVA was confirmed in grapevine following controlled transmissions with $P$. ficus although undecorated CV-like particles were present. The reliability of the ELISA detection procedure appears to be influenced by seasonal fluctuations in GVA concentrations.
\end{abstract}

In 1980 Conti et al. reported the isolation of a closterovirus (CV) from a grapevine showing stem pitting symptoms. This virus, provisionally named grapevine stem pitting-associated virus (GSP-AV), was mechanically transmitted to Nicotiana clevelandii Gray, purified and shown to have a particle length of $800 \mathrm{~nm}$. Using an antiserum prepared to GSP-AV by Conti et al. (1980), Milne et al. (1984) later showed that GSP-AV occurs frequently, either alone or in association with another serologically unrelated $\mathrm{CV}$, in both leafroll and stem pitting diseased grapevines. The second $\mathrm{CV}$ was also found alone in some diseased plants, whereas one grapevine, indexed negative for leafroll, also contained GSP-AV particles. Consequently, Milne et al. (1984) suggested (a) changing the name grapevine stem pitting-associated virus to grapevine virus A (GVA), and (b) provisionally referring to the second virus as grapevine virus $B$.

In ISEM and decoration tests and using the same antiserum to GVA, we demonstrated the presence of GVA in the root extracts of several Vitis vinifera L. cv. Waltham Cross 22/3 sources and the grapevine seedling LN-33 (a Vitis hybrid) source 3/77 (Engelbrecht \& Kasdorf, 1985). The LN-33 source was one of 12 vines out of 100 showing leafroll symptoms two seasons after being interplanted in a leafroll-infected $V$. vinifera $\mathrm{cv}$. Tinta Barocca vineyard. We also showed that virus transmitted from leafroll-infected vines by the mealybug Planococcus ficus Signoret to $N$. clevelandii was serologically similar to GVA and that GVA was present in extracts of $P$. ficus that had fed on a leafroll source (Engelbrecht \& Kasdorf, 1985).

The present study reports on the preparation of antisera and its use to determine the occurrence and means of transmission of GVA in grapevine.

\section{MATERIALS AND METHODS}

\section{Virus purification and antiserum production:}

A source of Waltham Cross clone 22/3 ex Jacques (Paarl) carrying GVA was used throughout to transmit virus by $P$. ficus to $N$. clevelandii plants as described previously (Engelbrecht \& Kasdorf, 1985).

GVA was purified from freshly harvested or frozen systemically infected $N$. clevelandii leaves, using method B as described by Conti et al. (1980) with minor modifications. The concentration of polyethylene glycol (MW6000) was increased to $8 \%$ to improve the precipitation of virus from the aqueous phase following chloroform $(20 \% \mathrm{v} / \mathrm{v})$ clarification. Final purification of virus was performed on a $10-40 \%$ linear gradient of glycerol in 0,05 $\mathrm{M}$ sodium phosphate buffer, $\mathrm{pH} 7,5$ and centrifuged at $25000 \mathrm{rpm}$ for $180 \mathrm{~min}$ in a Beckman SW27 rotor. The single lower virus band at $c a$. $35 \mathrm{~mm}$ from the meniscus, as determined by electron microscopy, was withdrawn, the glycerol removed by dilution in $0,05 \mathrm{M}$ sodium phosphate buffer $\mathrm{pH} 7,5$ and the virus pelleted at $50000 \mathrm{rpm}$ for $45 \mathrm{~min}$ in a Beckman rotor Ti50.

The concentration of resuspended virus in $\mathrm{mg} / \mathrm{m} l$ was estimated using the relation $\mathrm{E}(1 \mathrm{mg} / \mathrm{ml}, 260 \mathrm{~nm}, 1 \mathrm{~cm})$ $=4,8$ calculated according to Gibbs \& Harrison (1976) from the ratio $\mathrm{A}_{260} / \mathrm{A}_{280}=1,5$ reported by Boccardo \& D'Aquilio (1981). Yields of GVA based on $A_{260}$ measurements varied between 200 and $500 \mu \mathrm{g} / 100 \mathrm{~g}$ leaf tissue depending on the time of year. Higher virus yields were usually obtained with material harvested during late autumn to early spring.

Antisera to GVA were produced in rabbits and goats. An initial intravenous injection was followed at 2 -week intervals by several subcutaneous injections in 
Freund's incomplete adjuvant. Virus concentration varied from 200 to $500 \mu \mathrm{g}$ per injection. The animals were bled at 2 -week intervals following the third injection. Titres of the antisera, collected from the various bleedings, were determined by the slide precipitin test against purified virus. Antisera with maximum titres of $1 / 1024$ and 1/8 192 in rabbit and goat, respectively, were obtained.

\section{Extraction of virus:}

Grapevine tissue, consisting mainly of bark of actively growing shoots or scrapings of underlying green tissue of dormant cuttings, were macerated in liquid $\mathrm{N}_{2}$ and resuspended $\mathrm{m} / 5 \mathrm{v}$ in $0,1 \mathrm{M}$ sodium phosphate buffer $\mathrm{pH} \mathrm{7,0}$ containing $2 \%$ polyvinylpyrrolidone and $0,5 \%$ casein. The extract was centrifuged at $10000 \mathrm{rpm}$ for $10 \mathrm{~min}$ and the supernatant retained for ELISA tests. Plant extracts as well as extracts prepared from mealybug (4-6 females in a few drops of extracting buffer), used in electron microscope investigations, were prepared similarly except that casein and low-speed centrifugation were omitted. Instead, the macerate was left for 5-10 min to allow fibrous material to settle to the bottom of the tube, leaving a relatively clear supernatant.

\section{Immunosorbent electron microscopy (ISEM) with dec- oration:}

ISEM was performed as previously described (Engelbrecht \& Kasdorf, 1985) except that for trapping the $\mathrm{CV}$, antiserum was diluted $1 / 1000$ in $0,1 \mathrm{M}$ sodium phosphate buffer $\mathrm{pH} \mathrm{7,0}$ and the trapping time extended to overnight at room temperature. Grids were decorated (Milne \& Luisoni, 1977) with the same antiserum diluted $1 / 100$, and finally negatively stained in $2 \%$ aqueous uranyl acetate before viewing in the electron microscope. Rabbit antiserum to GVA with a titre of 1/1 024 was used.

\section{Enzyme-linked immunosorbent assay (ELISA):}

An indirect double antibody sandwich ELISA procedure, using horseradish peroxidase-antiperoxidase (PAP) complex for the detection of GVA in field-collected grapevine material (Engelbrecht, Rowland \& Du Toit, 1987 and unpublished data) was employed.* Wells of microtitre plates (Nunc-Immuno plate II no. 4

\section{TABLE 1}

Observation on the virus status of visually examined grapevines

\begin{tabular}{|c|c|c|c|c|c|}
\hline \multirow{3}{*}{ Cultivar } & \multirow{3}{*}{ Source } & \multirow{3}{*}{ Symptoms ${ }^{\text {a) }}$} & \multicolumn{3}{|c|}{$\begin{array}{l}\text { Detection procedure with grape- } \\
\text { vine virus } A(G V A) \text { antiserum }{ }^{\text {b) }}\end{array}$} \\
\hline & & & \multicolumn{2}{|c|}{ ISEM \& decoration } & ELISA \\
\hline & & & \multicolumn{3}{|c|}{$\begin{array}{c}\text { Closterovirus- } \\
\text { like }\end{array}$} \\
\hline Barlinka 27 & Exhex, De Doorns & $\mathrm{RL}$ & + & + & $*$ \\
\hline Barlinka 27 & Welgemoed, Sandhills & $\mathrm{RL}$ & - & - & - \\
\hline Barlinka 27 & Bella Vista, De Doorns & $\mathrm{RL}$ & - & - & $*$ \\
\hline Barlinka 47 & Welgemoed, Sandhills & LR & + & $+c)$ & + \\
\hline Barlinka 47 & Exp. Farm, De Doorns & LR & + & $+c)$ & + \\
\hline C. Sauvignon & Labori, Paarl & LR & + & + & + \\
\hline C. Saugvignon & Klein Lanzerac, Stellenbosch & NS & - & - & - \\
\hline C. Sauvignon & Klein Lanzerac, Stellenbosch & LR & + & + & + \\
\hline Dauphine & Lentelus, De Doorns & LR & + & + & $*$ \\
\hline Malbec & Stellenbosch University & LR & + & + & + \\
\hline Malbec & Stellenbosch University & $\mathrm{SD}$ & + & + & + \\
\hline Merlot & Stellenbosch University & $\mathrm{SD}$ & + & + & + \\
\hline Merlot & Stellenbosch University & LR & + & + & + \\
\hline Pinot noir & Groenhof, Stellenbosch & $\mathrm{RL}$ & + & $+c)$ & + \\
\hline SA Riesling & Nietvoorbij, Stellenbosch & LR & + & $+c)$ & + \\
\hline SA Riesling & Phesantekraal, Durbanville & NS & - & - & - \\
\hline SA Riesling & Groenhof, Stellenbosch & LR & + & + & + \\
\hline Shiraz & Phesantekraal, Durbanville & LR & + & + & + \\
\hline Shiraz & Glen Connor, Stellenbosch & LR & + & + & + \\
\hline Shiraz & Glen Connor, Stellenbosch & $\mathrm{SD}$ & + & + & + \\
\hline Shiraz & Groenhof, Stellenbosch & LR & + & + & + \\
\hline Shiraz & Groenhof, Stellenbosch & $\mathrm{SD}$ & + & + & + \\
\hline Waltham Cross & Non Pareil, De Doorns & LR & + & + & + \\
\hline Waltham Cross 22 & Non Pareil, De Doorns & NS & - & - & - \\
\hline
\end{tabular}

a $\mathrm{LR}=$ leafroll, $\mathrm{SD}=$ Shiraz disease, $\mathrm{RL}=$ red leaf, $\mathrm{NS}=$ no symptoms

$\mathrm{b}+=$ positive,$-=$ negative,${ }^{*}=$ not tested

c Reacted to Gugerli's closterovirus type I antiserum 
-42404 ) were coated by incubation at $37^{\circ} \mathrm{C}$ for $2 \mathrm{~h}$ with whole goat antiserum (titre $1 / 2048$ ) diluted $1 / 200$ in 0.1 $\mathrm{M}$ carbonate buffer, $\mathrm{pH} 9,6$. The plates were rinsed with phosphate-buffered saline, $\mathrm{pH} 7,4$ (PBS) and then blocked by incubation at $37^{\circ} \mathrm{C}$ for $2 \mathrm{~h}$ with casein buffer $(0,5 \%$ casein in $0,01 \mathrm{M}$ tris- $\mathrm{HCl}, \mathrm{pH} 7,6$ containing saline and $0,02 \%$ Thiomersal). Plates were then emptied and test samples added to duplicate wells before incubation overnight at $4^{\circ} \mathrm{C}$. Following rinsing with $\mathrm{PBS}$ containing $0,05 \%$ Tween-20 (PBS-T) whole rabbit antiserum (titre $1 / 1024$ ), diluted $1 / 50$ in casein buffer, was added to the plates and incubated at $37^{\circ} \mathrm{C}$ for $2 \mathrm{~h}$. After further rinsing with PBS-T sheep anti-rabbit IgG (Miles), diluted in casein buffer $1 / 100$, was added and incubated at $37^{\circ} \mathrm{C}$ for $2 \mathrm{~h}$. The plates were again rinsed with PBS-T, the PAP reagent (Miles), diluted 1/10 000 in casein buffer, added and further incubated at $37^{\circ} \mathrm{C}$ for $2 \mathrm{~h}$. The wells were finally rinsed in PBS-T and the peroxidase substrate added (2,2-azinodi- (3-ethyl benzthiazoline sulfonic acid) (ABTS) in $0,1 \mathrm{M}$ citrate-phosphate buffer, $\mathrm{pH} 5,0$, containing $0,06 \%$ hydrogen peroxide). The plates were incubated for $30 \mathrm{~min}$ at room temperature in the dark and the colour developed was read on a Titertek Multiscan plate reader (Flow) at 405 $\mathrm{nm}$. Background readings of healthy control grapevine extracts were normally 0,005 or less. Readings of greater than 0,010 were therefore considered positve. An appropriate infected control was included in each plate.

\section{Virus transmission by mealybug from vine to vine:}

Plants of Waltham Cross clone 22/3 ex Jacques (Paarl) were colonised during the autumn of 1984 with crawlers and adult females of $P$. ficus, previously reared on virus-free white sprouting potatoes. Following an acquisition access time of about 2 weeks, the insects were allowed an inoculation access time of about 2 weeks on healthy LN-33 vines (Experiments 1 \& 2, Table 4). Controls included LN-33 vines colonised with mealybugs taken directly from the same batch of potatoes (Experiment 3, Table 4) and LN-33 vines without mealybugs (Experiment 4, Table 4). Also included in the trial for comparison were LN-33 plants chip-budded at the same time with material obtained from the virusinfected donor (Experiment 5, Table 4). Transmissions were carried out under optimum breeding conditions for P. ficus (Engelbrecht \& Kasdorf, 1985). At the con-

TABLE 2

Observation on the virus status of indexed grapevine

\begin{tabular}{|c|c|c|c|c|c|}
\hline \multirow{3}{*}{ Cultivar } & \multirow{3}{*}{ Source } & \multirow{3}{*}{$\begin{array}{l}\text { Disease } \\
\text { status }^{\text {a) }}\end{array}$} & \multicolumn{3}{|c|}{$\begin{array}{l}\text { Detection procedure with grape- } \\
\text { vine virus } A(G V A) \text { antiserumb) }\end{array}$} \\
\hline & & & \multicolumn{2}{|c|}{ ISEM \& decoration } & ELISA \\
\hline & & & \multicolumn{3}{|c|}{$\begin{array}{l}\text { Closterovirus- } \\
\text { like }\end{array}$} \\
\hline Barlinka 27 (P201/1) & SAPO, Ceres & $\mathrm{H}$ & - & - & - \\
\hline Barlinka $47(\mathrm{P} 216 / 1)$ & SAPO, Ceres & $\mathrm{H}$ & - & - & - \\
\hline Cinsaut (P163/12) & P\&S, Stellenbosch & LR, SD & + & $+c)$ & + \\
\hline Emperor (I5) & P\&S, Stellenbosch & $\mathrm{CB}, \mathrm{LR}$ & + & + & * \\
\hline Grenache noir (P29) & P\&S, Stellenbosch & $\mathrm{F}$ & - & - & - \\
\hline Merlot noir (I1064) & P\&S, Stellenbosch & SP & - & - & - \\
\hline 101-14 Mgt (P428) & P\&S, Stellenbosch & $\mathrm{F}$ & - & - & - \\
\hline NIT-6 (P518) & P\&S, Stellenbosch & $\mathrm{F}$ & - & + & - \\
\hline Pais (I253) & P\&S, Stellenbosch & $\mathrm{CB}, \mathrm{LR}$ & - & + & $*$ \\
\hline 1103 Paulsen (I1033) & P\&S, Stellenbosch & SP & - & - & - \\
\hline 779 Paulsen (I334) & P\&S, Stellenbosch & $\mathrm{F}$ & - & - & - \\
\hline Pinot blanc (I1037) & P\&S, Stellenbosch & SP & - & - & - \\
\hline Pinot noir (I1056) & P\&S, Stellenbosch & SP & - & - & - \\
\hline Pinot noir (I1083) & P\&S, Stellenbosch & $\mathrm{SP}$ & - & - & - \\
\hline SA Riesling (P667) & P\&S, Stellenbosch & F,LR,CB,SP & + & + & + \\
\hline Seyve Villard (I685) & P\&S, Stellenbosch & $\mathrm{F}$ & - & - & - \\
\hline Shiraz (P50) & P\&S, Stellenbosch & $\mathrm{F}, \mathrm{LR}, \mathrm{CB}, \mathrm{SP}$ & + & + & $*$ \\
\hline Shiraz (P50/1) & P\&S, Stellenbosch & $\mathrm{H}$ & - & - & $*$ \\
\hline Shiraz (P122/5) & P\&S, Stellenbosch & $\mathrm{H}$ & - & - & - \\
\hline Shiraz (P122/6). & P\&S, Stellenbosch & LR & + & $+c)$ & * \\
\hline Waltham Cross 22/3 & La Concord; Paarl & LR,SP & + & $+c)$ & + \\
\hline Weisser Riesling (I1055) & P\&S, Stellenbosch & $\mathrm{F}$ & - & + & - \\
\hline
\end{tabular}

a $\mathrm{LR}=$ leafroll, $\mathrm{SD}=$ Shiraz disease, $\mathrm{SP}=$ stem pitting, $\mathrm{F}=$ fleck, $\mathrm{CB}=$ corky bark, $\mathrm{H}=$ healthy

$\mathrm{b}+=$ positive, $-=$ negative, ${ }^{*}=$ not tested

c Reacted to Gugerli's closterovirus type I antiserum 

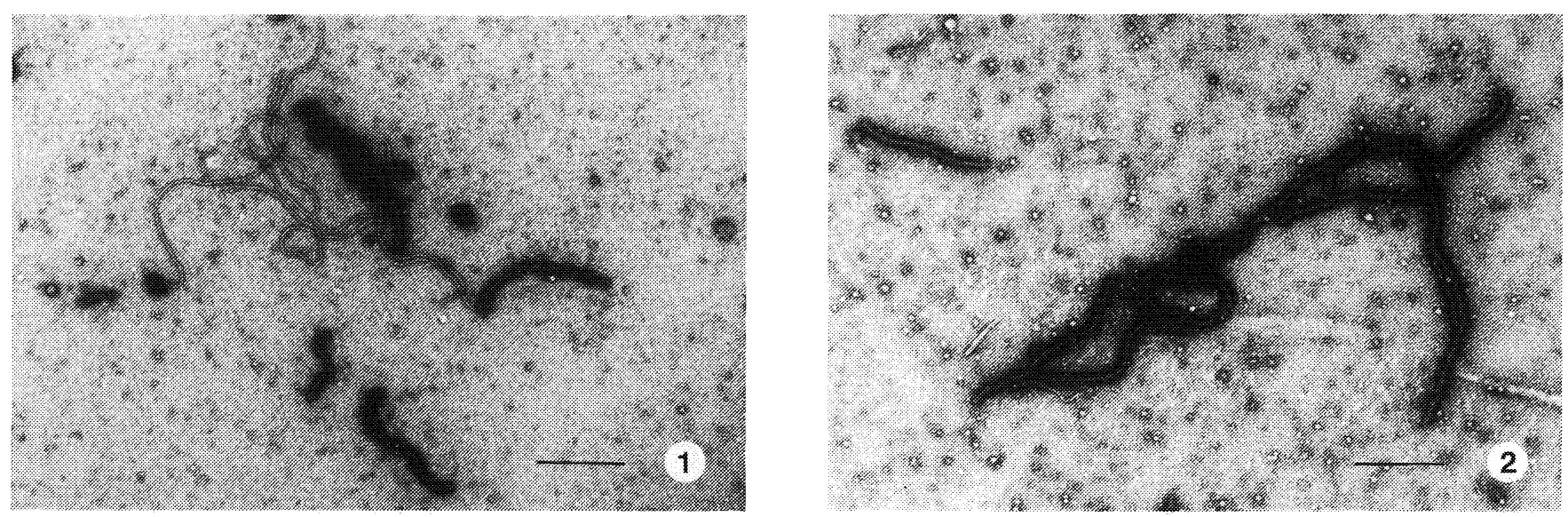

FIG. A

Closteroviruses in Waltham Cross 22/3 infected with leafroll and stem pitting diseases. (1). Grapevine virus A (GVA) particles trapped (1/1 000) and decorated (1/100) with homologous GVA antiserum. Note undecorated longer closterovirus-like particles. (2). Grapevine closterovirus type I particles trapped (1/1 000) and decorated (1/100) with Gugerli's closterovirus type I antiserum. Magnification bars $=500 \mathrm{~nm}$.

clusion of the transmission experiments all vines were sprayed with Ultracide $(1 \mathrm{~g} / l)$, transferred to an insectproof gauze-house compartment and kept under observation.

\section{RESULTS}

\section{Virus status of grapevine sources:}

GVA was consistently found present in grapevine sources showing either visual symptoms or indexing positive for leafroll (Tables $1 \& 2$ ). In addition, GVA was detected in all the vine sources showing Shiraz disease (Engelbrecht \& Kasdorf, 1985) symptoms. Conversely, GVA was absent or not detectable in grapevine sources indexing positive for either fleck or stem pitting alone. The four sources which indexed negative for graft-transmissible diseases (Table 2) were all derived from ca. $5-10 \mathrm{~mm}$ tip-cuttings which received various periods of heat treatment at $37^{\circ} \mathrm{C}$. Tests showed these sources to be free from GVA despite the presence, for instance, of GVA and CV-like particles in the mother plant (P50) of the $V$. vinifera cv. Shiraz P50/1 source.

The electron microscope provided additional information on the presence of CV-like particles. These particles were longer than the $800 \mathrm{~nm}$ GVA particle. Using an antiserum to CV $2200 \mathrm{~nm}$ (CV type I) kindly provided by Dr P Gugerli, Station Federal de Recherches Agronomiques de Changins, CH-1260, Nyon, Switzerland (Gugerli, Brugger \& Bovey, 1984) the presence of the latter CV was detected in several instances in local grapevine sources (Tables $1 \& 2$ ). Despite the presence of both CV type I and GVA in the Waltham Cross 22/3 source (Fig. A), only GVA was transmitted from this source to N. clevelandii by P. ficus (Fig. B). Moreover, extracts of $P$. ficus also revealed the presence of both GVA and CV type I particles (Fig. C). The availability
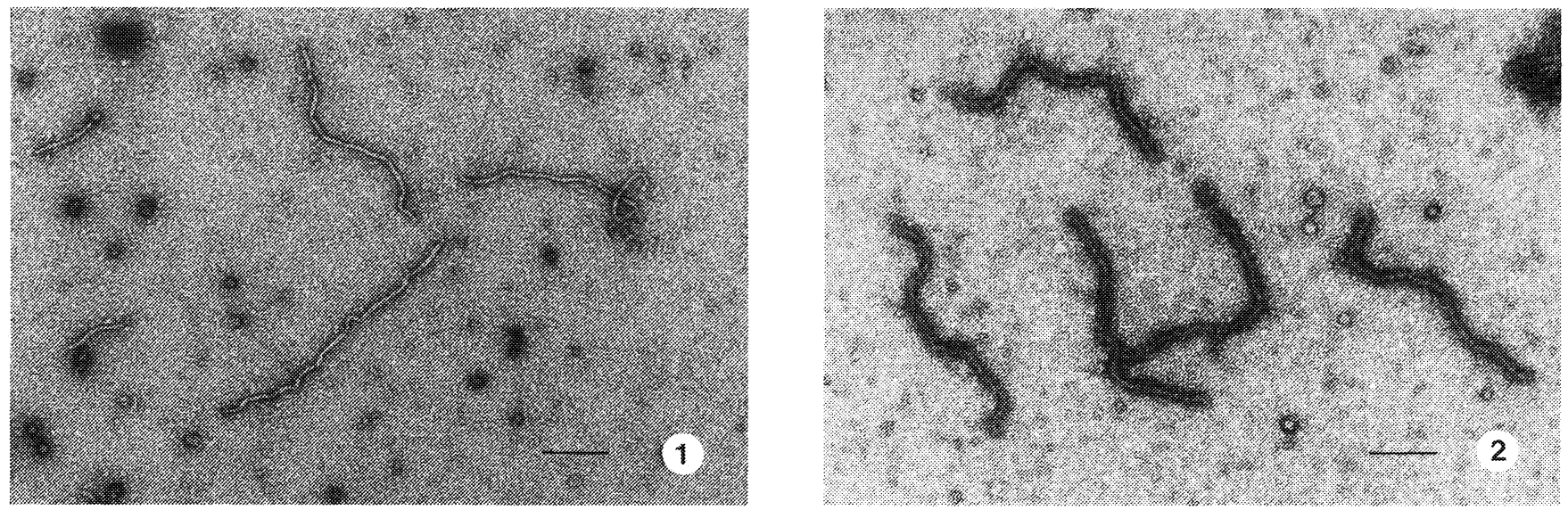

FIG. B

GVA transmitted from Waltham Cross $22 / 3$ by $P$. ficus to $N$. clevelandii. (1). Virus particles negatively stained with $2 \%$ uranyl acetate. (2). GVA particles trapped (1/1 000) and decorated (1/100) with homologous GVA antiserum. Magnification bars $=200 \mathrm{~nm}$. 

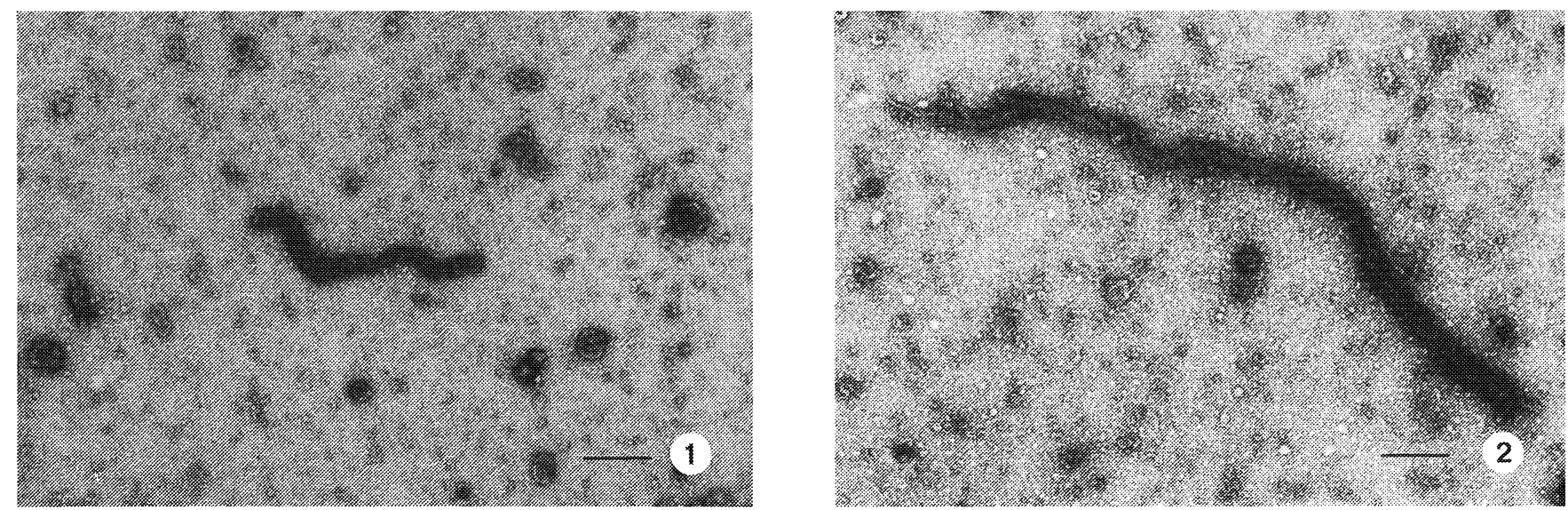

FIG. C

Acquisition of closteroviruses by $P$. ficus following a feed on Waltham Cross 22/3 vines. (1). GVA particles trapped $(1 / 1000)$ and decorated (1/100) with GVA antiserum. (2). Grapevine closterovirus type I particles trapped (1/1 000) and decorated (1/100) with Gugerli's closterovirus type I antiserum. Magnification bars $=200 \mathrm{~nm}$.

of an antiserum to CV type I also enabled the detection of a third CV-like particle in the Shiraz (P122/6) source (Fig. D). The undecorated particle was longer than GVA.

\section{Field spread of $\mathbf{G V A}$ to $\mathbf{L N}-33$ vines:}

GVA was detected by both ELISA and ISEM with decoration tests in extracts prepared from the dormant canes of 10 interplanted LN-33 vines showing leafroll symptoms (Table 3). However, when the ELISA tests were repeated with bark extracts from actively growing shoots from the same vines during the following spring, three vines were negative $\left(\mathrm{A}_{405}=0,061 c f .0,000\right)$. The average GVA concentration $\left(\mathrm{A}_{405}=0,325 c f\right.$. 0,080) was also reduced. Furthermore, undecorated CV-like particles were detected only in vines with a relatively high GVA concentration.

\section{Mealybug transmission of GVA to LN-33 vines:}

During the autumn of 1985 and again in 1986 a mild rolling and reddish discolouration appeared on the leaves of some of the LN-33 test vines in Experiments 1 \& 2 (Table 4). Both ELISA and microscope screening tests with tissue extracts prepared from dormant bark revealed the presence of GVA in these vines $\left(\mathrm{A}_{405}=\right.$ $0,017 c f$. ISEM with decoration, GVA+). Moreover, electron microscope observations confirmed a direct correlation between GVA concentration and ELISA readings (Vine $2 c f$. vine 5 in Experiment 2). Absence of virus in the control vines (Experiments $3 \& 4$ ) confirmed the absence of GVA in the potatoes used for rearing the mealybugs and initial healthy status of the LN-33 vines. Particles of both GVA and CV type I were present in LN-33 vines (Experiment 5) chipbudded with material from the Waltham Cross 22/3 vines, as well as in extracts of mealybugs that fed on the latter (Fig. C). The presence of $\mathrm{CV}$ type $\mathrm{I}$ in vines of Experiments $1 \& 2$ could, however, not be confirmed due to lack of antiserum.
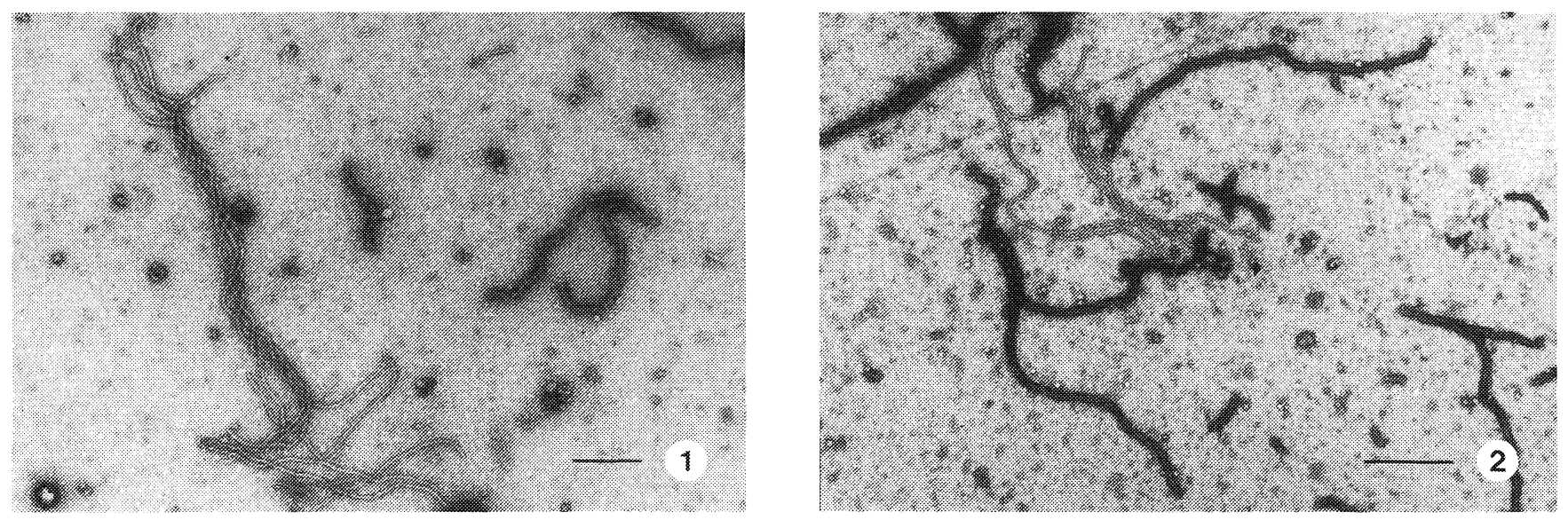

FIG. D

Detection of a third closterovirus-like particle in Shiraz (P122/6). (1). GVA particles trapped (1/1 000) and decorated (1/100) with GVA antiserum. Note undecorated longer closterovirus-like particles. Magnification bar $=200$ $\mathrm{nm}$ (2). Grapevine closterovirus type I particles trapped (1/1 000) and decorated (1/100) with Gugerli's closterovirus antiserum. Note undecorated closterovirus-like particles longer than GVA. Magnification bar $=500 \mathrm{~nm}$. 
TABLE 3

Observation on the virus status of initially healthy $\mathrm{LN}-33$ indicator vines interplanted in a leafroll-infected Tinta Barocca vineyard, Durbanville

\begin{tabular}{|c|c|c|c|c|c|}
\hline \multirow{4}{*}{$\begin{array}{l}\text { Indicator } \\
\text { Vine No. }\end{array}$} & \multirow{4}{*}{$\begin{array}{l}\text { Health } \\
\text { status }^{\text {a }}\end{array}$} & \multicolumn{4}{|c|}{$\begin{array}{l}\text { Detection procedure with grape- } \\
\text { vine virus A (GVA) antiserum }\end{array}$} \\
\hline & & \multicolumn{2}{|c|}{$\begin{array}{l}\text { ISEM with decoration of } \\
\text { dormant canes }^{\text {b) }}\end{array}$} & \multicolumn{2}{|c|}{ ELISA } \\
\hline & & \multirow[b]{2}{*}{$\begin{array}{l}\text { Decorated } \\
\text { particles }\end{array}$} & \multirow{2}{*}{$\begin{array}{l}\text { Undecorated } \\
\text { closterovirus- } \\
\text { like particles }\end{array}$} & \multicolumn{2}{|c|}{$\mathrm{A}_{405^{\mathrm{c}}}$} \\
\hline & & & & $\begin{array}{l}\text { Dormant } \\
\text { canes }\end{array}$ & $\begin{array}{l}\text { Growing } \\
\text { shoots }\end{array}$ \\
\hline $2-65$ & $\mathrm{LR}^{\mathrm{d})}$ & + & + & 0,365 & 0,130 \\
\hline $2-76$ & $\mathrm{LR}^{\mathrm{d})}$ & + & + & 0,531 & 0,101 \\
\hline $2-95$ & LR & + & + & 0,466 & 0,119 \\
\hline $3-76$ & $\mathrm{LR}^{\mathrm{d})}$ & + & + & 0,551 & 0,135 \\
\hline $3-77$ & $\mathrm{LR}^{\mathrm{d})}$ & + & + & 0,547 & 0,156 \\
\hline 3-194 & LR & + & + & 0,650 & 0,146 \\
\hline $5-103$ & LR & + & - & 0,026 & 0,000 \\
\hline $5-139$ & $\mathrm{LR}^{\mathrm{d})}$ & + & - & 0,061 & 0,000 \\
\hline $5-145$ & LR & + & - & 0,043 & 0,011 \\
\hline $5-162$ & LR & + & - & 0,019 & 0,001 \\
\hline LN-33 Control & & - & - & 0,000 & 0,000 \\
\hline
\end{tabular}

a Visual symptoms: $\mathrm{LR}=$ Leafroll

$\mathrm{b}+=$ positive,$-=$ negative

c Mean values of 4 replications

d Indexed positive for Leafroll

\section{DISCUSSION}

The results confirm the widespread presence of GVA in grapevine sources with leafroll symptoms or indexing positive for leafroll in biological tests. Limited screening of grapevine sources indexing positive for either fleck or stem pitting revealed no detectable GVA, which suggests that it is probably not associated with either of these diseases. Furthermore, GVA in grapevine sources, showing Shiraz disease, appears to be incidental and probably due to latent infection with leafroll. The presence of partially decorated and undecorated CV-like particles in association with GVA indicated that several viruses are probably involved in the grapevine leafroll disease complex. One of these viruses, CV type I was identified in several local grapevine sources. Moreover, the presence of a CV-like particle longer than GVA in an extract of Shiraz P122/6 that did not react with antiserum to the CV type I suggests that at least two serologically unrelated long CVs are present in local grapevine sources. The unidentified longer CV could either be identical with the $1800 \mathrm{~nm}$ CV (CV type II) of Gugerli et al. (1984) or with the third undecorated $\mathrm{CV}$ recently reported by Rosciglione \& Gugerli (1986) in grapevine. Partially decorated CVlike particles were also observed by Milne et al. (1984) who suspected that the phenomenon might be due to end-to-end aggregation. Rosciglione \& Gugerli (1986) recently concluded, after extensive screenings of Italian vines, that particles of the CV types I and II are associated with leafroll. However, they were unable to demonstrate a similar association between leafroll and short CV particles of GVA because their method did not allow separation of these particles from fragments of long particles damaged during extraction. Contrary to our findings they concluded that the GVA particle is not obligatorily associated with leafroll but perhaps with grapevine stem pitting.

The presence of GVA and undecorated CV-like particles was also confirmed in the interplanted LN-33 vines visually infected and indexed positive for leafroll which suggests spread of virus from surrounding Tinta Barocca vines, known to carry GVA and CV-like particles (unpublished data). Furthermore, controlled transmission studies showed that $P$. ficus was able to acquire both GVA and the CV type I virus, and to transmit GVA and CV-like particle to vines which eventually showed leafroll-like symptoms. Further studies on the causative viruses will, however, be necessary to resolve the aetiology of the leafroll disease. To this end the production of appropriate antisera to the longer CVs already identified by Gugerli et al. (1984), Milne et al. (1984) and Rosciglione \& Gugerli (1986) will be essential.

The two virus screening procedures corroborated the presence or absence of GVA in grapevine sources. However, it seems imperative that plant material should be taken under optimum conditions to ensure reliable results. From limited tests it already appears that higher GVA concentration can be expected in dormant canes. 


\section{TABLE 4}

Observations on the virus status of LN-33 indicator vines following colonisation with Planococcus ficus, which were given an acquisition access time on leafroll-infected Waltham Cross 22/3 vines

\begin{tabular}{|c|c|c|c|c|}
\hline \multirow{3}{*}{$\begin{array}{l}\text { Experiment/ } \\
\text { Vine No. }\end{array}$} & \multicolumn{4}{|c|}{ Detection procedure with grapevine virus A (GVA) antiserum } \\
\hline & \multicolumn{3}{|c|}{ ISEM with decoration ${ }^{\text {a) }}$} & \multirow{2}{*}{$\frac{\text { ELISA }}{\mathrm{A}_{400^{\circ}}^{\circ}}$} \\
\hline & $\begin{array}{c}\text { Decorated } \\
\text { particles }\end{array}$ & $\begin{array}{l}\text { tion of closte } \\
\text { like particles } \\
\text { Partially } \\
\text { decorated } \\
\end{array}$ & Undecorated & \\
\hline $\begin{array}{l}\text { Experiment } 1 \\
\text { Vine } 1 \\
\text { Vine } 2 \\
\text { Vine } 3 \\
\text { Vine } 4 \\
\text { Vine } 5 \\
\text { Vine } 6\end{array}$ & $\begin{array}{l}+ \\
\frac{+}{+} \\
\frac{-}{-}\end{array}$ & $\begin{array}{l}+ \\
\frac{-}{+} \\
-\end{array}$ & $\begin{array}{l}- \\
z \\
z \\
-\end{array}$ & $\begin{array}{l}0,050 \\
0,000 \\
0,000 \\
0,355 \\
0,000 \\
0,000\end{array}$ \\
\hline $\begin{array}{l}\text { Experiment } 2 \\
\text { Vine } 1 \\
\text { Vine } 2 \\
\text { Vine } 3 \\
\text { Vine } 4 \\
\text { Vine } 5 \\
\text { Vine } 6\end{array}$ & $\begin{array}{c}- \\
++ \\
- \\
\overline{+} \\
++\end{array}$ & $\begin{array}{l}\overline{+} \\
\overline{-} \\
+\end{array}$ & $\begin{array}{l}\overline{+} \\
- \\
- \\
-\end{array}$ & $\begin{array}{l}0,000 \\
0,603 \\
0,000 \\
0,000 \\
0,017 \\
0,223\end{array}$ \\
\hline $\begin{array}{l}\text { Experiment } 3 \\
\text { Vine } 1 \\
\text { Vine } 2 \\
\text { Vine } 3\end{array}$ & E & E & E & $\begin{array}{l}0,000 \\
0,000 \\
0,000\end{array}$ \\
\hline $\begin{array}{l}\text { Experiment } 4 \\
\text { Vine } 1 \\
\text { Vine } 2 \\
\text { Vine } 3\end{array}$ & E & E & - & $\begin{array}{l}0,000 \\
0,000 \\
0,000\end{array}$ \\
\hline $\begin{array}{l}\text { Experiment } 5 \\
\text { Vine } 1 \\
\text { Vine } 2\end{array}$ & $\begin{array}{l}+++ \\
+++\end{array}$ & $\begin{array}{l}+ \\
+\end{array}$ & $\begin{array}{l}+c) \\
+\end{array}$ & $\begin{array}{l}0,509 \\
0,577\end{array}$ \\
\hline
\end{tabular}

a $+=$ positive, $-=$ negative

$\mathrm{b}$ Mean values of 4 replications

c Reacted to Gugerli's closterovirus type I antiserum

\section{LITERATURE CITED}

BOCCARDO, G. \& D'AOUILIO, M., 1981. The protein and nucleic acid of a closterovirus isolated from a grapevine with stem pitting symptoms. J. Gen. Virology 53, 179-182.

CONTI, M., MILNE, R.G,. LUISONI, E. \& BOCCARDO, G., 1980. A closterovirus from a stem pitting diseased grapevine. Phytopathology 70, 394-399.

ENGELBRECHT, D.J. \& KASDORF, G.G.F., 1985. Association of a closterovirus with grapevines indexing positive for grapevine leafroll disease and evidence for its natural spread in grapevine. Phytopath Medit. 24, 101-105.

ENGELBRECHT, D.J., ROWLAND, G.F. \& DU TOIT, W., 1987. An indirect enzyme-linked immunosorbent assay (ELISA) using a peroxidase-anti-peroxidase (PAP) complex for the detection of plant viruses. (Abstr.) Phytophylactica (In press).

GIBBS, A. \& HARRISON, B., 1976. Plant virology: the principles Edward Arnold (Publishers) Ltd, London, p. 116.
GUGERLI, P., BRUGGER, J.J. \& BOVEY, R., 1984. L'enroulement de la vigne: mise en évidence de particules virales et développement d'une méthode immuno-enzymatique pour le diagnoistic rapide. Revue Suisse Vitic. Arboric, Hortic 16, 299-304.

MILNE, R.G., CONTI, M., LESEMANN, D.E., STELLMACH, G., TANNE, E. \& COHEN, J., 1984. Closterovirus-like particles of two types associated with diseased grapevines. Phytopath. Z.110, 360-368.

MILNE, R.G. \& LUISONI, E., 1977. Rapid immuno-electron microscopy of virus preparations. Pages 265-281 in: Methods in Virology Vol. 6. K. Maramorosch \& H. Koprowski, eds. Academic Press, New York.

ROSCIGLIONE, B. \& GUGERLI, P., 1986. Maladies de l'enroulement et du bois strié de la vigne: analyse microscopique at sérologique. Revue Suisse Vitic. Arboric. Hortic. 18, 207-211. 